\title{
Upacara Ngelangkang Pengaus Sebagai Wujud Yajna Umat Hindu Kaharingan Suku Dayak Lawangan
}

\author{
Nali Eka, Melky Setiawan, dan Komang Suarta \\ Universitas Hindu Indonesia Denpasar, IAHN-TP Palangka Raya, IAHN-TP Palangka Raya \\ nalieka@iahntp.ac.id,Melkysetiawan9@gmail.com,kicakkirana@gmail.com
}

\section{Riwayat Jurnal}

Artikel diterima: 17 Juni 2019

Artikel direvisi: 25 Juni 2019

Artikel disetujui: 25 Juni 2019

\section{Kata Kunci:}

Ngalangkang pengaus,

Panca yajna,

Hindu Kaharingan Dayak Lawangan

\section{Abstrak}

Suku Dayak Lawangan yang beragama Hindu Kaharingan memiliki suatu upacara kematian yang dilaksanakan setahun setelah upacara kematian yaitu upacara ngalangkang yang memiliki arti untuk memperingati kematian dari keluarga yang meninggal. Upacara tersebut dilaksanakan setiap tahun sebanyak tiga tahun berturut-turut dan puncaknya yaitu ditahun ketiga yang merupakan ngalangkang pengaus atau ngalangkang terakhir. Upacara ngalangkang pengaus merupakan penerapan ajaran tri kerangka dasar Agama Hindu yaitu tattwa, susila, dan upacara. Nilai tattwa terlihat dalam keyakinan umat Hindu suku Dayak Lawangan pada struktur ketuhanan bahwa segala sesuatu berasal dari Juss Tuha Allah Taala dan akan kembali kepadaNya. Nilai susila yang terkadung dalam Upacara Ngalangkang Pengaus, yaitu sesuai dengan ajaran agama Hindu seperti ajaran pitra rna, punia, tidak boleh berjudi, tidak boleh mada dan tidak boleh sastraghana. Nilai upacara yang terkandung dalam Upacara ngalangkang pengaus adalah rangkaian upacara dan upakara yang merupakan jalan atau cara umat Hindu mendekatkan diri kepada Tuhan. Upacara ngalangkang pengaus pada umat Hindu suku Dayak Lawangan merupakan implementasi dari semua ajaran panca yajna yaitu ajaran dewa yajna, pitra yajna, rsi yajna, manusa yajna dan bhuta yajna, namun yang paling utama upacara ngalangkang pengaus merupakan bentuk penerapan dari pitra yajna.

Keyword:

Ngalangkang pengaus,

Panca yajna,

Hindu Kaharingan Dayak Lawangan

\section{Abstract}

The Dayak Lawangan tribe who are Hindu Kaharingan have a death ceremony which is held a year after the death ceremony, namely the ngalangkang ceremony which means to commemorate the death of a deceased family. The ceremony is held every year as many as three consecutive years and the peak 


\begin{tabular}{|l|l|}
\hline is in the third year which is ngalangkang pengaus or ngalangkang \\
last. The ngalangkang pengaus ceremony is the application of the \\
tri teachings of the basic framework of Hinduism namely tattwa, \\
susila, and ceremony. The value of tattwa is seen in the belief of \\
Dayak Lawangan Hindus in the divine structure that everything \\
comes from Juss Tuha Allah Taala and will return to Him. Moral \\
values are contained in the Ngalangkang Pengaus Ceremony, \\
which is in accordance with the teachings of Hinduism such as \\
the teachings of pitra rna, punia, may not gamble, may not be \\
permitted and may not be sastraghana. The ceremonial value \\
contained in the ngalangkang pengaus ceremony is a series of \\
ceremonies and upakara which are the way or the way Hindus \\
draw closer to God. The ngalangkang pengaus ceremony for \\
Dayak Lawangan Hindus is an implementation of all the five \\
yajna teachings, namely the teachings of the yajna deity, yajna \\
pitra, yajna rsi, manusa yajna and bhuta yajna, but the most \\
important ngalangkang pengaus ceremony is the application of \\
pitra yajna
\end{tabular}




\section{Pendahuluan}

Upacara merupakan kewajiban bagi umat Hindu baik yang menyangkut dengan kelahiran, kehidupan dan kematian. Umat Hindu percaya bahwa upacara berhubungan dengan keharmonisan, baik keharmonisan hubungan dengan Tuhan, alam dan sesama manusia. Upacara yang dilaksanakan oleh umat Hindu erat kaitannya dengan Yadnya atau korban suci yang diuraikan dalam ajaran panca yajna. Ajaran panca yajna mengajarkan untuk melakukan suatu upacara korban suci secara tulus ikhlas tanpa mengharapkan suatu imbalan atau balasan.

Dayak Lawangan merupakan salah satu suku Dayak yang berada di Barito khususnya berada di Kabupaten Barito Selatan yang penyebarannya di Kecamatan Gunung Bintang Awai yaitu di Desa Patas I, Desa Patas II, Desa Bawo, dan Desa Bipak Kali. Dayak Lawangan masih memegang teguh keyakinan leluhur Kaharingan yang sekarang disebut dengan Hindu Kaharingan serta masih melaksanakan berbagai upacara baik menyangkut kehidupan maupun upacara menyangkut kematian. Pada suku Dayak Lawangan yang beragama Hindu terdapat suatu upacara kematian yang dilaksanakan setahun setelah upacara kematian, yaitu upacara ngalangkang yang memiliki arti untuk memperingati kematian dari keluarga yang meninggal.

Upacara ngalangkang tersebut dilaksanakan setiap tahun sebanyak tiga tahun berturut-turut dan puncaknya, yaitu ditahun ketiga yang merupakan ngalangkang pengaus atau ngalangkang terakhir. Upacara ngalangkang merupakan salah satu upacara penting dalam keyakinan umat Hindu Kaharingan Dayak Lawangan, namun belum sepenuhnya dipahami tata cara, proses, fungsi dan maknanya. Begitupula keterlibatan dan partisipasi umat dalam kegiatan juga rendah padahal upacara ngalangkang pengaus merupakan sarana pembelajaran; tata cara mempersiapkan sarana, dan tahapan pelaksanaan upacara ngalangkang pengaus yang berlangsung dari hari pertama sampai selesai. Regenerasi pengetahuan upacara ngalangkang pengaus sangat penting agar keberadaan upacara ini dapat terus lestari sebagai salah satu wujud panca yajna umat Hindu suku Dayak Lawangan.

\section{Metode}

Penelitian ini digunakan pendekatan deskriptif kualitatif untuk mengumpulkan data, yaitu menggunakan teknik wawancara, observasi dan dokumentasi. Dalam kegiatan observasi di lapangan, peneliti bertindak sebagai observasi partisipan. Dilakukan observasi terhadap pelaksanaan upacara Ngelangkang Pengaus umat Hindu Kaharingan suku Dayak Lawangan 
di Desa Bipak Kali Kabupaten Barito Selatan. Penelusuran kondisi masa lampau dilakukan dengan menelaah dokumen dan melakukan rekonstruksi melalui wawancara analisis di lapangan. Materi yang digunakan sebagai bahan wawancara dalam penelitian ini adalah halhal yang berkaitan dengan permasalahan yang akan dikaji. Peneliti menggunakan teknik purposive sampling untuk menentukan informan sesuai dengan tujuan yang ingin dicapai dalam penelitian ini. Informan dipilih yang relevan dan mengetahui serta memahami mengenai masalah yang akan diteliti. Sesuai dengan pertimbangan tersebut maka peneliti menetapkan empat orang Mantir Adat, satu orang Penghulu Adat dan satu orang dari pengurus Majelis Kelompok Agama Hindu Kaharingan Desa Bipak Kali. Disamping sumber informan sebagai sumber primer, dilakukan pula penelahan tekstual kitab suci Hindu dan penelitian terdahulu. Adapun proses analisis data meliputi reduksi data (data reduction), penyajian data (data display), serta penarikan kesimpulan dan verifikasi (conclusion drawing/ verification).

\section{Pembahasan}

\section{Proses Upacara Ngelangkang Pengaus pada Umat Hindu Kaharingan Suku Dayak Lawangan}

Upacara tidak pernah lepas dari kegiatan sehari-hari umat Hindu baik yang menyangkut persembahyangan, maupun upacara-upacara yang berkaitan dengan kehamilan, kelahiran, kehidupan dan kematian (Chulsum, Umi, \& Novia, 2006, hal. 687):

Upacara diartikan sebagai tanda-tanda kebesaran, peralatan (menurut adat-istiadat), rangkaian tindakan atau perbuatan yang terikat pada aturan tertentu menurut adat atau agama, perbuatan atau perayaan yang dilakukan atau diadakan sehubungan dengan peristiwa penting.

Dalam ajaran agama Hindu upacara masuk dalam tri kerangka dasar selain susila dan tattwa. Upacara berasal dari dua kata yaitu upa yang berarti dekat atau mendekati, dan cara yang berakar dari kata car yang memiliki arti harmonis, seimbang, selaras. Sehingga upacara dapat diartikan dengan keseimbangan, keharmonisan dan keselarasan dalam diri untuk mendekatkan diri dengan Tuhan. Pada suku Dayak Lawangan yang beragama Hindu Kaharingan terdapat upacara ngalangkang yang dilaksanakan setahun sesudah kematian untuk memperingati kematian anggota keluarga dan dilaksanakan tiga tahun berturut-turut dimana ditahun ketiga merupakan puncak upacara ngalangkang tersebut yang disebut ngalangkang pengaus atau ngalangkang terakhir. Menurut (Nahan, Fattah, \& dkk, 2014, hal. 22) "upacara ngalangkang dalam suku Dayak Lawangan termasuk dalam tingkatan kedua 
diupacara kematian yang disebut wara selain upacara wara mate (orang meninggal) dan wara ngungkat (mengangkat tulang)". Upacara ngalangkang pengaus tersebut merupakan puncak upacara ngelangkang atau ngelangkang yang terakhir, karena pada umat Hindu suku Dayak Lawangan upacara ngalangkang hanya dilaksanakan sebanyak tiga tahun berturut-turut.

Proses dalam upacara ngalangkang pengaus meliputi tiga tahapan, yaitu tahap persiapan, tahap kegiatan pokok dan tahap penutup. Berikut ini merupakan uraian dari setiap tahapan dalam proses upacara ngalangkang pengaus:

\section{Tahap Persiapan}

Sejak jauh hari keluarga telah bermusyawarah untuk menetapkan waktu dan tempat pelaksanaan upacara ngalangkang pengaus. Setelah disepakati bersama, maka selanjutnya adalah memberitahukan kepada pelaksana upacara seperti Mantir dan Penghulu Adat tentang waktu dan tempat pelaksanaan upacara ngalangkang pengaus. Tempat pelaksanaan upacara ngalangkang pengaus adalah di rumah tempat almarhum tersebut ketika meninggal, tetapi dapat juga dilaksanakan di rumah keluarga yang lain dengan ketentuan apabila memindahkan tempat pelaksanaan ngalangkang pengaus, maka pemilik rumah tempat meninggal harus bayar utang adat atau disebut nyurung lantai sebanyak keje 4 atau bila dirupiahkan sebanyak Rp. 20.000,00 kepada pemilik rumah untuk tempat pelaksanaan ngalangkang pengaus.

Upacara ngalangkang pengaus dilaksanakan dengan mempersiapkan hewan korban atau persembahan kepada liau (roh) berupa piak metem (ayam kampung berbulu hitam), upe (babi kandang/ babi kampung) dan sesajian lainnya. Persembahan hewan korban piak metem dilakukan karena menurut kepercayaan bahwa umat Hindu suku Dayak Lawangan liau tersebut sudah berbeda dunia dengan manusia tidak bisa dilihat dengan mata oleh sebab itu disimbolkan dengan warna hitam, sedangkan apabila hewan korban upe bermakna bahwa persembahan tersebut besar karena keluarga iklas mempersembahkan hewan korban kepada liau. Pada saat ngalangkang pengaus persembahan atau makanan berupa tusukan sate, kue basah, kue kering dan sebagainya dibuat sebanyak 21 buah.

Umat Hindu Kaharingan suku Dayak Lawangan memiliki kepercayaan bahwa hal yang berkaitan dengan koe mate (kegiatan yang menyangkut kematian) disimbolkan dengan angka tujuh jadi dalam upacara ngalangkang juga berlaku demikian. Persembahannya pada ngalangkang pertama dan kedua dibuat 7 , sedangkan pada ngelangkang pengaus sebanyak 21. Pada upacara ngalangkang, persembahan kepada liau (almarhum) laki-laki lebih banyak dari pada perempuan disebabkan umat Hindu Kaharingan suku Dayak Lawangan di Desa 
Bipak Kali mengartikan laki-laki merupakan sosok pemimpin, jadi persembahan dalam upacara ngalangkang pertama dan kedua harus berjumlah 14 sedangkan untuk perempuan berjumlah 7. Apabila dalam upacara ngalangkang pengaus baik laki-laki maupun perempuan jumlah persembahannya dibuat sama, yaitu 21 dikarenakan merupakan upacara ngalangkang puncak dan terakhir, jadi harus dibuat sebanyak 21. Menurut keyakinan suku Dayak Lawangan angka 21 diperoleh dari perkalian angka 7 yaitu angka kematian dengan angka 3 yang merupakan tahun ketiga dari upacara ngalangkang pengaus.

Susunan kegiatannya upacara ngalangkang pengaus terdapat tarung sundang (cerita perjalanan liau atau roh yang meninggal) yang dilaksanakan dihari ketiga setelah mengatarkan ansak ke pemakaman (dalam ngalangkang pertama dan kedua tidak ada). Tarung sundang dilaksanakan oleh Mantir dan turus wali pematang asbah dengan ketentuan, apabila tarung sundang dilaksanakan oleh turus wali pematang asbah maka tutup tarung-nya dibalas oleh Mantir Desa tersebut, namun apabila tarung sundang dilaksanakan oleh Mantir maka tutup tarung-nya dibalas oleh Mantir dari desa lain. Dalam upacara ngalangkang pengaus apabila ada sarana yang kurang maka upacara tersebut tetap berlanjut dengan ketentuan harus melunasi sanksi atas kekurangan tersebut yang disebut utang tong liau.

Orang yang melaksanakan upacara ngalangkang pengaus, yaitu Mantir Opat Penghulu Erai (Mantir Empat Penghulu Satu) dalam hal ini diartikan bahwa ada 4 orang Mantir dan seorang Penghulu Adat yang terlibat untuk melaksanakan upacara, sedangkan untuk membakar tusukan sate piak metem dan upe adalah pesambe (wanita tua yang tidak memili anak kecil yang masih menyusui). Namun para Mantir Kado (Mantir Muda yang baru memulai menjadi seorang Mantir) dapat juga bertugas dalam melaksanakan upacara ngalangkang pengaus apabila Mantir Kado tersebut memiliki kemampuan, pengetahuan dan berguru dari Mantir sebelumnya.

\section{Tahap Kegiatan Pokok}

Kegiatan pokok dari upacara ngalangkang pengaus adalah pada saat pelaksanaan upacara tersebut yang berlangsung selama 3 hari 2 malam. Sarana menjadi hal penting yang harus ada dalam upacara ngalangkang pengaus karena sarana tersebut harus dicari dan dipersiapkan agar tidak ada kesalahan dan kekurang yang terjadi selama upacara. (Setiawan, 2017, hal. 40-41) beberapa sarana yang harus dibuat dalam upacara ngalangkang pengaus meliputi: 
(a) ansak, wadah tempat makan atau tempat persembahan untuk liau, ansak ini dibuat dari bambu yang dipotong kecil yang dianyam lalu disatukan dengan cara diikat dengan rotan. (b) Lapir kelangkang, yaitu piring yang diletakan dibawah ansak dengan posisi terbalik yang memiliki arti sebagai alas ansak atau menjadi alas piring untuk tempat makan liau. (c) Lilit kelangkang (kain hitam) yang dililit di ansak yang memiliki arti untuk pembatas roh masyarakat agar tidak ikut makan di ansak ketika mantir sedang melaksanakan upacara memberi makan liau. (d) Buyung tutu adalah kain hitam yang menjadi pembatas roh Mantir yang memberi makan liau atau pada saat melaksanakan upacara ngalangkang pengaus. (e) Tusuk untuk alat berupa tusuk untuk memanggang daging babi dan ayam yang menjadi persembahan untuk memberi makan liau dicari dan dibuat sebanyak 21 buah tusuk. (f) Tolang (bambu) yang berukuran besar yang digunakan untuk wadah memasak lamang yang menjadi makanan masyarakat dan keluarga pelaksana upacara ngalangkang pengaus. (g) Bane liau adalah bambu kecil yang digunakan untuk memasak lamang sebagai persembahan kepada liau. (h) Luen liau adalah daging upe (babi) yang dimasak dalam bambu besar dan pendek sebagai lauk atau gulai untuk persembahan kepada liau. (i) Tolang kaos (bambu kecil dan pendek) dicari 7 buah dan disatukan dengan cara diikat. Tolang kaos ini diartikan sebagai tempat cuci tangan Liau. (j) Sangker liau yang diisi air putih, air kopi, air teh dan air tuak yang menjadi minuman bagi liau pada saat memberi makan Liau tersebut. (k) Bibit tanaman yang diyakini dibawa oleh liau untuk menjadi bekal bertanam. Bibit tanaman yang dicari adalah bibit padi, bibit pisang, bibit tebu dan bibit kelapa. (1) Wadai (kue basah maupun kue kering) dibuat berjumlah 21 dan kue tersebut dibuat berdasarkan kesukaan liau (orang yang meninggal) sewaktu masih hidup. (m) Hewan yang menjadi korban persembahan yaitu piak metem (ayam berbulu hitam) dan upe (babi). (n) Rokok yang dipersiapkan untuk liau, yaitu rokok yang dibuat sendiri dengan melinting kertas rokok yang diisi dengan tembakau atau menggunakan rokok yang beredar di pasaran. (o) Sempa merupakan daun sirih yang diisi dengan pinang dan dioles kapur lalu digulung. (p) Bulu tundu ilem nutui (parang) yang digunakan oleh Mantir untuk menunjuk makanan pada saat memberi makan liau agar dilihat oleh liau.

Rangkaian upacara ngalangkang pengaus dimulai dihari pertama, yaitu pada siang hari masyarakat dan keluarga yang terlibat dalam upacara ngalangkang pengaus melakukan beberapa kegiatan seperti membuat rempah-rempah, membersihkan dan memotong ayam, membersihkan dan memotong sayur kemudian memasak nasi dan lauk yang telah dipersiapkan sebelumnya kemudian setelah semua selesai maka dilanjutkan makan bersama. Pada malam hari dilaksanakan basarah yang bertujuan untuk mengawali kegiatan upacara ngalangkang pengaus agar berjalan dengan lancar dengan memohon perlindungan kepada Juss Tuha Allah Taala/Ranying Hatalla Langit. Kegiatan berikutnya yaitu petuet turus wali pematang asbah atau yang diartikan musyawarah untuk mencari ahli waris dari almarhum keluarga yang meninggal. Dilanjutkan, kegiatan petuet turus wali pematang asbah pihak lakilaki dari keluarga yang merasa tuturnya (silsilah keturunan) lebih tua dari almarhum yang telah meninggal satu persatu berdiri untuk berbicara dan menceritakan tutur (silsilah) keluarganya dengan almarhum tersebut hingga saatnya salah satu dari laki-laki tersebut yang 
terpilih menjadi turus wali pematang asbah dan yang menjadi penanggung jawab dari pihak keluarga selama upacara ngalangkang pengaus berlangsung.

Hari kedua, pada pagi hari keluarga dan masyarakat yang terlibat dalam upacara Ngalangkang Pengaus melaksanakan beberapa kegiatan diantaranya menyiapkan bahan sesajian dan bahan konsumsi selama upacara. Upe (babi) yang menjadi hewan korban dipotong yang kemudian dipisah antara yang menjadi konsumsi masyarakat dan yang menjadi persembahan kepada liau. Bagian upe yang menjadi persembahan kepada liau adalah bagian kerokot (kaki), urung (hidung) dan lola (lidah). Di malam harinya masyarakat berkumpul menyiapkan sesajian yang akan digunakan pada esok harinya, selain itu dilaksanakan petuet Mantir atau penyerahan dari turus wali pematang asbah kepada Mantir tentang niat untuk melaksanakan ngalangkang pengaus agar Mantir dapat memutuskan hukum adat dan susunan kegiatan yang akan dilaksanakan keesokan harinya. Bukti penyerahan dari turus wali pematang asbah adalah berupa tabak erai daon (meja Mantir), kemudian lumbah opat atau piring yang disusun empat diisi dengan beras, uang Rp.4.000,00 dan telur ayam. Makna dari lumbah opat adalah sebagai penebus atau pembayaran jika ada dari pihak keluarga yang berperasaan tidak baik atau tidak harmonis dengan keluarga lain saat melaksanakan upacara, maka harus ditebus atau dibayar dengan lumbah opat.

Hari ketiga atau hari terakhir upacara ngalangkang pengaus dilaksanakan beberapa kegiatan diantaranya mencari bahan untuk membuat ansak (dari bambu dan rotan), membakar bane liau, luen liau dan tusukan sate hewan korban yaitu piak metem dan upe untuk persembahan kepada liau yang dilakukan oleh pesambe. Pada saat pesambe membakar tusuk sate, di dalam rumah para laki-laki membuat ansak sebagai tempat persembahan kepada liau kemudian diletakan bulu piak metem dan bunge pare (bunga padi) disekeliling ansak yang berjumlah 14 untuk laki-laki dan 7 untuk perempuan yang bermakna bahwa telah selesai melaksanakan upacara ngalangkang pengaus.

Tahap selanjutnya dilanjutkan dengan mengisi dengan tusukan sate hewan korban yang telah dibakar sebanyak 21 tusuk, wadai (kue) basah maupun kue kering sebanyak 21 , lamang sebanyak 21, buah seadanya, nasi biasa dan nasi ketan. Di ansak digantung tolang kaos dan sangker liau. Petugas yang mengisi ansak atau tempat persembahan adalah keluarga dari almarhum dan harus menggunakan tangan kiri.

Pada saat mengisi ansak oleh keluarga almarhum, pesambe dan Mantir mengarahkan agar semua anggota keluarga terlibat untuk mengisi ansak dan juga memberikan arahan untuk 
meletakan sarana yang telah dipersiapkan agar tersusun sesuai dengan aturan. Susunan mengisi persembahan dalam ansak dimulai dari nasi biasa maupun nasi ketan, wadai basah dan kering, tusukan sate, luen liau, bane liau dan buah-buahan. Setelah ansak diisi maka Mantir menyerahkannya kepada Balian Tundru yang bertugas memberi makan atau memberikan persembahan kepada liau untuk melaksanakan kegiatan selanjutnya. Setelah diterima oleh Balian Tundru maka ansak dan sarana lainnya seperti bibit tanaman, air kopi, air teh, air tuak, rokok dan sempa dibawa ke Lebeng (pemakaman) dan yang membawanya adalah pihak keluarga dari liau tersebut.

Di Lebeng dilaksanakan kegiatan untuk memberi makan atau memberikan persembahan kepada liau oleh Balian Tundru dengan mengucapkan mantra untuk memanggil liau tersebut agar datang dari Gunung Lumut untuk menerima persembahan yang telah dipersiapkan. Perantara antara Balian Tundru dengan liau tersebut adalah Putri Luing Boyas yang bertugas untuk menyampaikan maksud dari Balian Tundru untuk memberikan persembahan kepada liau.

Usai memberikan persembahan kepada liau maka keluarga dan masyarakat yang ikut ke Lebeng (pemakaman) kembali ke rumah tempat upacara dan kemudian dilanjutkan dengan makan bersama. Setelah makan bersama maka upacara selanjutnya, yaitu tarung sundang. Prosesi tarung sundang, Mantir yang terpilih bercerita mengenai liau dari mulai ngalangkang pertama sampai ngalangkang pengaus belum bisa mencapai Ja Karang Intan Benua Sapu Amas (surga) karena belum cukup bekal atau persembahan yang diterima dari pihak keluarga. Kemudian setelah tarung sundang dilanjutkan dengan tutup tarung, yaitu Mantir yang terpilih mengisahkan perjalan roh selama upacara ngalangkang hingga pada akhirnya setelah diberi persembahan yang cukup. Pada akhirnya liau tersebut melanjutkan perjalananya menuju ke Ja Karang Intan Benua Sapu Amas dan telah disebut dengan Juss Kelelungan Aning Kalelio karena sudah bersatu dengan Juss Tuha Allah Taala atau Tuhan Yang Maha Kuasa dan menjadi Dewa penolong bagi keluarga yang ditinggalkan.

Prosesi tarung sundang telah dilaksanakan maka kegiatan berikutnya yaitu pembersihan sawuh (hal kotor) yang dilakukan oleh Mantir kepada seluruh orang yang terlibat dalam upacara ngalangkang pengaus dari pengaruh koe mate (kegiatan yang menyangkut kematian) dengan memercikan tatungkal (tirta atau air suci). Kegiatan selanjutnya menurut (Setiawan, 2017, hal. 52-53) yaitu pembayaran hukum adat dengan rincian pembayaran sebagai berikut. 
(a) Ngene ansak kelangkang adalah orang yang membuat ansak dibayar sebesar Rp. $1.000,00$ (b) Ngene okan liau adalah orang yang membuat atau memasak untuk persembahan kepada liau dibayar dengan ketentuan apabila yang meninggal laki-laki Rp. 1.400,00 apabila yang meninggal perempuan Rp. 700,00. (c) Makan liau adalah orang yang bertugas memberi persembahan kepada liau atau dalam kata lain pemberi makan liau dibayar Rp. 1.500,00. (d) Lilit kelangkang, buyung tutu, lapir kelangkang, adalah kain hitam dan piring alas ansak ini bisa di bayar Rp.3.000,00 atau bisa langsung diberikan barang tersebut kepada Balian Tundru. (e) Ihau inyam adalah barang yang di pinjam dari rumah orang lain pada saat pelaksanaan upacara ngalangkang pengaus dibayar Rp. 250,00 tiap rumah. (f) Betatungkal adalah orang yang membersihkan seluruh anggota keluarga dan masyarakat yang terlibat dalam upacara ngalangkang pengaus dengan cara memercikan air air suci dibayar $\mathrm{Rp}$. 1.750,00. (g) Penowus tabak pesesarah (meja Mantir) Rp. 7.000,00 diberikan kepada Matir yang terpilih pada saat kegiatan petuet Mantir apabila tidak dibayar maka barang tersebut akan menjadi miliknya.

\section{Tahap Kegiatan Penutup}

Upacara ngalangkang pengaus diakhiri atau ditutup dengan memberikan tembai (upah) kepada orang-orang yang bertugas melaksanakan upacara ngalangkang pengaus khususnya kepada para Mantir dan Penghulu Adat, tokoh agama Hindu Kaharingan suku Dayak Lawangan dan tokoh adat. Tembai yang diberikan dalam bentuk uang seikhlasnya dan juga sesajen yang ada dalam upacara ngalangkang pengaus diberikan bagiannya kepada pelaksana upacara seperti lamang dan wadai.

\section{Nilai-nilai Upacara Ngalangkang Pengaus Pada Umat Hindu Suku Dayak Lawangan}

Upacara ngalangkang pengaus mengandung nilai-nilai ajaran tri kerangka dasar Hindu yaitu tattwa, susila dan upacara. Nilai tattwa yang terkandung dalam upacara ngelangkang pengaus dapat terlihat ketika doa-doa atau mantra yang diucapkan ditujukan kepada Tuhan disebut dengan Juss Tuha Allah Taala yang merupakan awal dari semua hal dan semua hal akan kembali kepada-Nya. Dalam keyakinan umat Hindu Kaharingan suku Dayak Lawangan roh yang menghidupi tubuh mahluk hidup disebut dengan Juss yang nantinya akan kembali kepada Juss Tuha Allah Taala melalui proses kematian. Pada saat kematian roh tersebut berubah sebutan menjadi liau dan cara untuk mengantarkan liau tersebut ke Ja Karang Intan Benua Sapu Amas (surga) dan bersatu dengan Juss Tuha Allah Taala adalah melalui upacara ngalangkang pengaus. Sehingga pelaksanaaan upacara ngelangkang pengaus ini mengandung nilai tattwa. Umat Hindu Kaharingan suku Dayak Lawangan yakin bahwa dengan melaksanakan upacara ngalangkang pengaus berarti liau tersebut telah kembali dan bersatu dengan Juss Tuha Allah Taala serta menjadi Dewa 
penolong bagi keluarga yang ditinggalkan. Selain itu setiap memulai kegiatan upacara ngalangkang pengaus, umat Hindu Kaharingan suku Dayak Lawangan selalu melaksanakan basarah (Persembahyangan) pada malam pertama dengan tujuan untuk memohon kepada Juss Tuha Allah Taala atau Tuhan Yang Maha Esa agar menyertai upacara yang dilaksanakan sehingga dapat berlangsung dengan lancar tanpa ada hal yang menghalangi. Melaksanakan basarah merupakan berwujudan pelaksanaan ajaran widhi tattwa. Sebagaimana tertulis dalam Bhagawad Gita 4.11 dalam (Prabhupada, 2017, hal. 230) menyatakan:

Ye yathā mām prapadyante tāims tathaiva bhajāmy aham

Mama vartmānuvartante manuṣyāḥ pārtha sarvaśạ̣

Artinya:

Sejauh mana semua orang menyerahkan diri kepada-Ku, aku menganugerahi mereka sesuai dengan penyerahan dirinya itu. Semua orang menempuh jalan-Ku dalam segala hal, wahai putra prtha.

Dalam upacara ngelangkang pengaus terdapat aturan-aturan yang mengikat pelaksana upacara baik yang berkaitan dengan sikap perilaku maupun tatacara berupacara yang menjadi acuan dalam pelaksanaan upacara. Pitra rna merupakan upacara yang dilaksanakan untuk membayar hutang kepada leluhur suku Dayak Lawangan yang dilaksanakan dalam bentuk upacara ngalangkang pengaus. Upacara ngalangkang pengaus wajib dilaksanakan dan menjadi tanggung jawab keluarga untuk melaksanakan guna melunasi hutang upacara. Melaksanakan upacara ngalangkang pengaus sebagai kewajiban dan rasa bakti merupakan wujud ajaran susila Hindu. Pelaksanaan ngalangkang pertama dan kedua untuk melunasi hutang kepada leluhur atau liau dari keluarga yang telah meninggal. Pihak keluarga yang bertanggung jawab untuk mengadakan upacara tersebut adalah turus wali pematang asbah atau ahli waris yaitu laki-laki dari strata keluarga tertua yaitu kakek atau paman.

Pada saat upacara ngalangkang pengaus umat Hindu suku Dayak Lawangan mempersembahkan hewan korban berupa piak metem dan upe. Hewan tersebut dikorbankan untuk kepentingan pitra puja. Sehingga umat Hindu suku Dayak Lawangan tidak sewenangwenang menyakiti atau membunuh hewan tetapi untuk kepentingan persembahan kepada leluhur dan keluarga yang telah meninggal. Ajaran ahimsa artinya tidak membunuh atau tidak menyakiti mahluk hidup lain dengan sewenang-wenang karena pembunuhan yang dilakukan sewenang-wenang berakibat dosa atau himsa karma. Namun membunuh mahluk hidup lain atau hewan diperbolehkan dalam agama Hindu apabila digunakan untuk kepentingan yadnya seperti: Dewa Puja yaitu membunuh untuk persembahan kepada para Dewa, pitra puja yaitu membunuh untuk persembahan kepada leluhur dan atithi puja yaitu membunuh untuk 
persembahan kepada tamu. Dalam pelaksanaan upacara ngalangkang pengaus terdapat pula penerapan ajaran punia yaitu perwujudan cinta kasih dengan memberikan sesuatu secara tulus ikhlas yang dapat diwujudkan salah satunya dengan melaksanakan Yadnya kepada Sang Hyang Widhi, para Rsi, leluhur dan bhuta kala. Pelaksana upacara dengan rasa cinta kasih dan tulus ikhlas mempersembahkan korban suci kepada Liau dalam upacara ngalangkang pengaus.

Selama upacara ngalangkang pengaus berlangsung tidak diperbolehkan permainan judi, namun usik liau (permainan liau) diperbolehkan, seperti keleker liau (dadu gurak/ permainan dadu) dan seramin liau (kartu remi). Usik liau yaitu permainan dadu gurak ataupun kartu remi yang dilakukan dengan menggunakan uang logam sebagai taruhan atau pembayaran dengan ketentuan hanya sebatas maksimal Rp. 2.100,00 apabila lebih dari ketentuan maka dianggap sebagai judi. Selama upacara ngalangkang pengaus tidak diperbolehkan melakukan judi karena ditakutkan dapat berdampak mengganggu pelaksanaan upacara. Demikian juga halnya dengan mada yang berarti mabuk yang timbul atau diakibatkan dari kekayaan, ketampanan atau kecantikan dan juga minum-minuman keras. Selama upacara ngalangkang pengaus tidak diperbolehkan mada atau mabuk minuman keras namun dalam petuet Mantir dan pada saat tarung sundang dapat minum tuak tetapi sebatas tiga kali putaran yang dinamakan Minum Adat namun tidak sampai mabuk.

Ajaran sastraghana diartikan sebagai perbuatan mengamuk sehingga mengakibatkan kerugian bagi orang lain dan juga diri sendiri juga menjadi hal yang dilarang selama berlangsungnya upacara. Perilaku yang diatur selama upacara ngalangkang pengaus adalah perilaku yang menimbulkan kerugian dalam upacara seperti berkelahi atau membuat keributan. Ketika terjadi kerugian dalam upacara, maka pelaku pembuat keributan akan dikenakan denda adat yaitu mengganti semua kerugian yang diakibatkan, membayar denda adat sebesar keje 16 atau Rp. 80.000,00 dan juga hewan korban upe untuk melaksanakan saki pilah atau pembersihan atau penyucian dengan menggunakan darah upe tersebut.

Pada saat upacara juga terdapat ketentuan berupa keterampilan berbicara beretika dalam pander jampa agar tidak menyinggung perasaaan masyarakat yang hadir. Demikian juga halnya pada saat tarung sundang diperlukan keterampilan bertutur perjalanan liau agar pada saat bercerita tidak terjadi kesalahan. Hal ini merupakan penerapan ajaran manacika parisudha. Jadi selama pelaksanaan upacara sikap perilaku benar-benar harus dijaga. Sesuai dengan ajaran susila Hindu yang diajarkan dalam kitab Sarasamuccaya 157 dalam (Kajeng, 2004, hal. 130-131): 
Adrohah sarvabhutesu,

Kayena manasa gira,

Anugrahasca danam ca,

Silametadvidurbudha

Artinya:

Yang membuat matinya segala mahluk hidup, sekali-kali jangan hendaknya dilakukan dengan menggunakan trikaya, yaitu perbuatan dan pikiran. Adapun yang harus diikhtiarkan dengan trikaya, hanyalah pemberian dan sedekah saja, sebab itulah yang disebut sila, kata orang arif.

Nilai upacara dari ngalangkang pengaus ini terlihat dari rangkaian tatacara proses upacara ngelangkang pengaus. Dalam upacara ngalangkang pengaus terdapat nilai sakralnya sebuah upacara dimana diperlukan keterampilan yang baik dalam mempersiapkan sarana agar tidak kurang dan tidak terjadi kesalahan,

\section{Ritual Ngalangkang Pengaus sebagai wujud Panca Yajna umat Hindu Suku Dayak Lawangan}

Upacara ngelangkang pengaus merupakan salah satu upacara yang termasuk yajna menurut ajaran Hindu. Menurut Midastra (Widana, 2007, hal. 32) "panca yajna ini berasal dari dua kata yaitu panca yang berarti lima dan yajna yang artinya korban suci atau persembahan". Jadi, panca yajna ini dapat diartikan sebagai lima persembahan atau lima korban suci yang tulus ikhlas berdasarkan cinta kasih. Sebab apabila yajna tersebut dilakukan dengan tulus ikhlas dan penuh cinta kasih maka akan menimbulkan dampak yang baik bagi diri sendiri maupun bagi orang lain, hal tersebut sesuai dengan yang tertulis dalam kitab Bhagawat Gita III. 12 dalam (Pudja G. , 2003, hal. 78) yang berbunyi sebagai berikut.

Ishtan bhogan hi vo deva

Dasyante yajna bhavitah

Tair dattan apradayai bhyo

Yo bhunkte stena eva sah

Artinya :

Sesungguhnya keinginan untuk mendapatkan kesenangan telah diberikan kepadamu oleh para dewa karena yajnamu, sedangkan ia yang telah memperoleh kesenangan tanpa memberikan yajna sesungguhnya adalah pencuri

Yajna merupakan realisasi karma dan bhakti umat Hindu kepada Sang Hyang Widhi berserta manifestasi-Nya sebab didalam yajna terkandung nilai pengorbanan, ketulusikhlasan, kesucian hati dan sikap tanpa pamrih untuk mempersembahkan sesuatu. Panca Yajna teridiri dari bagian-bagian, yaitu: (1) Dewa yajna yaitu korban suci atau persembahan 
kepada Sang Hyang Widhi beserta manifestasinya. (2) Bhuta yajna yaitu korban suci atau persembahan kepada bhuta kala atau unsur-unsur alam semesta. (3) Pitra yajna yaitu korban suci atau persembahan kepada roh leluhur. (4) Rsi yajna yaitu korban suci atau persembahan kepada para Brahmana atau para Rsi atas jasa beliau dalam membina umat dan mengembangkan ajaran agama, (5) Manusa yajna yaitu korban suci atau persembahan kepada sesama manusia untuk membersihkan lahir dan batin (Surayin, 2002, hal. 3-4)

Upacara ngalangkang dilaksanakan tiga kali berturut-turut selama tiga tahun, saat tahun ketiga merupakan ngalangkang pengaus yang menjadi puncak atau menjadi upacara Ngalangkang terakhir yang dilaksanakan. Upacara ngalangkang pengaus pada suku Dayak Lawangan diartikan sebagai upacara membagi hasil yang terakhir kepada liau (roh) keluarga yang telah meninggal”. Upacara ngalangkang pengaus diartikan sebagai korban suci atau persembahan yang tulus ikhlas kepada liau (roh) keluarga yang telah meninggal. Upacara ngalangkang pengaus ini dilaksanakan setelah panen padi selesai dan hari pelaksanaannya ditetapkan sesuai dengan kesepakatan keluarga. Umat Hindu Kaharingan suku Dayak Lawangan percaya bahwa untuk memberi makan atau mempersembahkan korban suci kepada liau (roh) keluarga tersebut harus menggunakan beras baru baik beras biasa maupun beras ketan. Persembahaan memberi makan atau korban suci merupakan wujud rasa cinta kasih dan juga rasa hormat kepada roh keluarga yang telah meninggal. Jadi, dalam mempersembahkan sesuatu dalam upacara ngalangkang pengaus tidak boleh sembarangan. Selama pelaksanaan upacara ngalangkang pengaus tidak terdapat banyak pali atau larangan, hanya saja keluarga yang membawa ansak pada saat diantar ke Lebeng tidak boleh menoleh ke kiri, ke kanan dan ke belakang karena diyakini liau keluarga tersebut tidak akan sampai ke Ja Karang Intan Вепиа Sари Amas dan akan selalu kembali kedunia untuk menengok keluarganya.

\section{Nilai-Nilai Panca Yajna yang Terkandung Dalam Upacara Ngelangkang Pengaus}

\section{Dewa Yajna}

Dewa yajna adalah korban suci atau persembahan yang tulus ikhlas kepada Sang Hyang Widhi berserta manisfetasinya. Dalam upacara ngalangkang pengaus terdapat implementasi dari ajaran dewa yajna yaitu dalam bentuk basarah pada malam pertama yang bertujuan untuk memohon perlindungan Juss Tuha Allah Taala agar upacara ngalangkang pengaus berlangsung dengan lancar tanpa ada halangan sampai selesainya upacara tersebut. Selain itu bentuk ajaran dewa yajna selanjutnya yaitu pada keyakinan umat Hindu Kaharingan suku Dayak Lawangan bahwa tujuan upacara ngelangkang pengaus adalah 
menyucikan liau tersebut agar kembali kepada Juss Tuha Allah Taala dan menjadi Dewa penolong bagi keluarga yang masih hidup. Mereka berserah penuh kepada Juss Tuha Allah Taala sebagai awal dan akhir dari kehidupan. Dalam Bhagawad Gita X.8 (dalam (Prabhupada, 2017, hal. 511) menyatakan:

ahá̀ sarvasya prabhavo

mattah sarvaḿ prāvartate

iti matvā bhajante māḿn

budhā bhāva-samanvitāh

Terjemahan:

Aku adalah sumber segala dunia rohani dan segala dunia material. Segala sesuatu berasal dari-Ku. Orang bijaksana yang mengetahui kenyataan ini secara sempurna menekuni bhakti kepada-Ku dan menyembah-Ku dengan sepenuh hatinya.

\section{Rsi Yajna}

Rsi yajna adalah korban suci atau persembahan tulus ikhlas kepada para Rsi atau orang suci. Implementasi dari ajaran rsi yajna dalam upacara ngalangkang pengaus adalah pemberian tembai atau upah sebagai bentuk ungkapan rasa hormat dan terima kasih pihak keluarga kepada pelaksana upacara yaitu kepada Mantir, Penghulu Adat, dan pesambe yang telah melaksanakan upacara ngalangkang pengaus dari awal sampai dengan selesai. Mantir, Penghulu Adat dan pesambe menurut umat Hindu Kaharingan suku Dayak Lawangan termasuk orang suci karena jasanya dalam mengembangkan dan menerapankan ajaran agama termasuk memimpin jalannya upacara ngalangkang pengaus. Tembai yang diberikan kepada pelaksana upacara ngalangkang pengaus adalah dalam bentuk uang seikhlasnya dan persembahan yang ada dalam upacara seperti lamang, wadai dan daging upe. Dalam ajaran Hindu merupakan suatu kewajiban untuk menghormati Rsi atau para orang suci sebagaimana yang tertulis dalam Manawa Dharmaçastra, dipaparkan bahwa akan ada hasil yang dicapai seseorang apabila dengan kesadaran penuh tanpa ada maksud tertentu menghormati ibu, ayah, dan gurunya dalam hal ini para orang suci rohaniawan tentunya termasuk para Mantir, Penghulu Adat, dan Pesambe sebagai guru kerohanian yang telah melaksanakan upacara adalah mencapai alam Brahma, seperti yang tertulis dalam kitab Manawa Dharmaçastra. II. 233 (Pudja, Gede, \& Sudharta, 2012, hal. 125) bahwa:

Imam lokam mātŗbhaktyā

Pitrbhaktyā tu madhymam

Gurucicrusaya twewam

Brhmalokam samacnute. 
Terjemahan :

Dengan menghormati ibunya ia mencapai kebahagiaan di bumi ini, dengan menghormati ayahnya ia menikmati dunia tengah tetapi dengan ketaatan terhadap gurunya ia mencapai alam Brahma.

Memberikan tembai atau upah yang layak bagi para Mantir, Penghulu Adat, dan pesambe merupakan aplikasi nilai etika yang merujuk pada tingkah laku sopan santun, hormat dan terima kasih kepada para orang suci yang berjasa dalam kehidupan keagamaan.

\section{Pitra Yajna}

Umat Hindu Kaharingan suku Dayak Lawangan memiliki salah satu upacara yang disebut ngalangkang pengaus dimana upacara merupakan wujud nyata dari penerapan ajaran yajna dalam agama Hindu, khususnya lebih dominan pada upacara pitra yajna. Pitra yajna atau korban suci yang dipersembahkan secara tulus iklas kepada roh leluhur atau keluarga yang telah meninggal dengan tujuan untuk menyucikan roh tersebut. Umat Hindu Kaharingan suku Dayak Lawangan melaksanakan upacara ngalangkang pengaus yang termasuk koe mate (kegiatan yang menyangkut kematian) dengan tujuan untuk menyucikan liau keluarga yang telah meninggal agar liau keluarga tersebut dapat mencapai Ja Karangan Intan Benиa Sapu Amas (surga) dan bersatu dengan Juss Tuha Allah Taala atau Sang Hyang Widhi. Sebagaimana ajaran agama Hindu bahwa pitra yajna bertujuan untuk mengembalikan roh leluhur ke tempat asalnya. Leluhur adalah ciptaan Tuhan seperti yang dijelaskan dalam kitab Manawa Dharmacastra III.192 (Pudja, Gede, \& Sudharta, 2012, hal. 125) bahwa:

Akhrodanah saucaparah satatam brahmacarinah

Nyasta sastra mahabhagah pitarah purwadewatah

Artinya:

Roh leluhur adalah dewa-dewa yang pertama, bebas dari kemarahan, hati-hati terhadap kesuciannya, selalu jujur, tidak suka bertengkar dan kaya akan kebajikan

\section{Manusa Yajna}

Manusa yajna adalah korban suci atau persembahan yang tulus ikhlas kepada sesama manusia untuk membersihkan lahir dan batin. Upacara manusa yadnya adalah upacara persembahan suci yang tulus ikhlas dalam rangka pemeliharaan, pendidikan serta penyucian secara spiritual terhadap seseorang sejak terwujudnya jasmani di dalam kandungan sampai akhir kehidupan. Penerapan ajaran manusa yajna dalam upacara ngalangkang pengaus adalah pada saat Mantir melakukan kegiatan pembersihan keluarga dan masyarakat yang terlibat dalam upacara dengan cara memercikan air tatungkal agar semua orang yang hadir dalam upacara tersebut bersih dari sawuh (pengaruh kotor) dari upacara ngalangkang pengaus. 
Penjelasan Manawa Dharma Sastra V.109 (Pudja, Gede, \& Sudharta, 2012, hal. 186) menyatakan:

Adhir gatrani sudyanthi, manah styena sudyanthi widyattaphobhyam bhrtatma, budhir jnanena sudyati.

Artinya:

Tubuh dibersihkan dengan air, pikiran dibersihkan dengan kejujuran, jiwa (atma) dibersihkan dengan ilmu, akal (budhi) dibersihkan dengan kebijaksanaan

\section{Bhuta Yajna}

Bhuta yajna adalah korban suci atau persembahan kepada bhuta kala atau unsur-unsur alam semesta untuk menjaga keharmonisan hubungan agar dalam kehidupan umat manusia tidak terdapat halangan dan gangguan dari bhuta kala atau unsur alam semesta. Jadi, manusia memiliki peran penting agar perputaran roda kehidupan ini berjalan dengan harmonis. Jika manusia dalam melakoni hidup penuh keserakahan dan mengabaikan prinsip-prinsip Dharma maka kehancuran pasti terjadi. Yajña manusia mampu menciptakan hubungan yang harmonis dengan Tuhan, sesamanya, dan keharmonisan alam. Hal inilah yang menjadi alasan kenapa pada saat tarung sundang, Mantir ngolek (memberitahu) kepada Penunggu Jaa (Penjaga Desa) dan kepada para sahabat sehurun (penjaga diri) agar tidak salah sangka terhadap upacara yang dilakukan, bahwa acara tersebut ditujukan kepada roh yang meninggal dengan tidak bermaksud mengabaikan keberadaan Penunggu Jaa (Penjaga Desa) dan sahabat sehurun (penjaga diri). Sarana yang digunakan yaitu menggunakan beras, kemudian Mantir mengucapkan mantra yang isinya untuk memberitahukan kepada Penjaga Jaa dan sahabat sehurun tentang maksud pelaksanaan upacara ngalangkang pengaus.

Agama Hindu mengajarkan semua mahkluk dan seisi alam semesta ini dapat memberikan faedah bagi kehidupan, tetapi juga membahayakan dan mengancam kehidupan ini. Oleh karena itu manusia perlu mengharmoniskan kehidupannya dan hukum alam semesta yang telah mengatur tatanan kehidupan di alam semesta ini. Demikian juga halnya dengan Penjaga Jaa dan sahabat sehurun yang diyakini sebagai pelindung yang memberikan manfaat bagi kehidupan juga dapat membahayakan dan mengancam kehidupan manusia jika tidak diperlakukan secara layak. Ajaran agama Hindu telah memberikan tuntunan kepada kita betapa harusnya umat manusia di dunia ini saling memelihara satu dengan yang lainnya akan memberikan kebaikan yang tertinggi. Bhagawad Gita, III: 10 -11 (Pudja, Gede, \& Sudharta, 2012, hal. 311) menyatakan sebagai berikut. 
saha-yajnah prajah srstva

purovaca prajapatih

anena prasavisyadhvam

esa vo 'stv ista-kama-dhuk

Artinya:

Pada zaman dahulu kala prajapati menciptakan manusia dengan yadnya dan bersabda, dengan ini engkau akan mengembang dan akan menjadi kamadhuk dari keinginan.

devam bhavayata'nena

devan bhavayatanena

te deva bhavayantu vah

parasparam bhavayantah

sreyah param avapsyatha

Artinya:

Dengan melakukan ini engkau memelihara kelangsungan para dewa; semoga para dewata juga memberkahimu; dengan saling menghormati seperti itu, engkau akan mencapai kebajikan tertinggi.

\section{Kesimpulan}

Upacara ngalangkang pengaus merupakan upacara membagi hasil yang terakhir kepada liau keluarga yang telah meninggal, bisa juga diartikan sebagai korban suci atau persembahan yang tulus ikhlas kepada liau keluarga yang telah meninggal. Upacara ngalangkang pengaus ini dilaksanakan setelah panen padi selesai dan hari pelaksanaannya ditetapkan sesuai dengan kesepakatan keluarga. Sarana yang terdapat dalam upacara ngalangkang pengaus harus dibuat dan dipersiapkan selama pelaksanaan upacara berlangsung. Upacara ngalangkang pengaus berlangsung selama 3 hari 2 malam dan dilaksanakan di rumah almarhum tersebut meninggal atau bisa dilaksanakan di rumah keluarga yang lain dengan membayar hukum adat yang disebut nyurung lantai. Upacara ngalangkang pengaus smerupakan penerapan ajaran tri kerangka dasar Agama Hindu yaitu tattwa, susila, dan upacara. Nilai tattwa terlihat dalam keyakinan umat Hindu Suku Dayak Lawangan tentang struktur ketuhanan bahwa segala sesuatu berasal dari Juss Tuha Allah Taala dan akan kembali kepada-Nya. Nilai susila yang terkadung dalam upacara ngalangkang pengaus yaitu sesuai dengan ajaran agama Hindu seperti ajaran pitra rna, ahimsa, punia, tidak boleh berjudi, tidak boleh mada dan tidak boleh sastraghana. Nilai upacara yang terkandung 
dalam upacara ngalangkang pengaus adalah rangkaian proses tatacara upacara merupakan salah satu cara umat Hindu Kaharingan Dayak Lawangan dalam mendekatkan diri kepada Tuhan dalam rangka memperoleh keselamatan bagi roh keluarga mereka yang telah meninggal serta bagi keluarga yang masih hidup. Upacara ngalangkang pengaus pada umat Hindu suku Dayak Lawangan merupakan implementasi dari semua ajaran panca yajna yaitu ajaran dewa yajna, pitra yajna, rsi yajna, manusa yajna dan bhuta yajna, namun yang paling utama upacara ngalangkang pengaus merupakan bentuk penerapan dari pitra yajna.

\section{Daftar Pustaka}

Chulsum, Umi, \& Novia, W. (2006). Kamus Besar Bahasa Indonesia. Surabaya: Kashiko. Kajeng, N. (2004). Sarasamusccaya. Surabaya: Paramita.

Nahan, Fattah, A., \& dkk. (2014). Mengenal Dayak Lawangan Ma'anyan, Bakumpai dan Biaju. Jakarta: Equatorial Bumi Persada.

Prabhupada, S. S. (2017). Bhagavad-gita Menurut Aslinya Terjemahan dalam bahasa Indonesia dan bahasa Sansekerta. Jakarta: Hanuman Sakti.

Pudja, G. (2003). Bhagawat Gita (Pancama Veda). Jakarta: Pustaka Mitra Jaya.

Pudja, Gede, \& Sudharta, T. R. (2012). Manawa Dharmacastra (Manu Dharma Sastra). Denpasar: Widya Dharma.

Setiawan, M. (2017). Upacara Ngalangkang Pengaus Dalam Panca Yajna Pada Umat Hindu Suku Dayak Lawangan di Desa Bipak Kali Kabupaten Barito Selatan: Skripsi. Palangka Raya: STAHN-TP Palangka Raya.

Surayin, I. A. (2002). Melangkah Ke Arah Persiapan Upakara-Upakara Yajna . Surabaya: Paramita.

Widana, I. G. (2007). Lima Cara Beryajna. Denpasar: BP. 